\title{
Squamous cell carcinoma of liver and intrahepatic biliary tract
}

INSERM

\section{Source}

INSERM. (1999). Orphanet: an online rare disease and orphan drug data base. Squamous cell carcinoma of liver and intrahepatic biliary tract. ORPHA:424975

Squamous cell carcinoma of liver and intrahepatic biliary tract is an extremely rare, primary, malignant liver and biliray tract epithelial tumor originating in the intrahepatic bile duct epithelium histologically characterized by the presence of keratinization and/or intracellular bridges. Patients typically present abdominal pain in the right upper quadrant, jaundice, nausea, vomiting, anorexia, weight loss, fever and/or dyspepsia. 